Israel Law Review 55(1) 2022, pp 25-49. (C) The Author(s), 2021. Published by Cambridge University Press in association with the Faculty of Law, the Hebrew University of Jerusalem. This is an Open Access article, distributed under the terms of the Creative Commons Attribution licence (http:/ creativecommons.org/licenses/by/4.0/), which permits unrestricted re-use, distribution, and reproduction in any medium, provided the original work is properly cited.

doi:10.1017/S0021223721000182

\title{
The Rights of the Families of Missing Persons: Going Beyond INTERNATIONAL HUMANITARIAN LAW
}

\author{
Grażyna Baranowska* [D
}

First published online on 21 October 2021

The main aim of the article is to test how states implement international humanitarian law (IHL) with regard to the families of missing persons. The article shows relevant IHL shortcomings and compares them with rules applicable in cases of enforced disappearance. The national legislation collected in the section titled 'The Missing and Their Families' of the National Implementation Database of the International Committee of the Red Cross is then examined. The analysis addresses three core questions that are particularly relevant for families of missing persons: (1) Who is considered a missing person under each law? Approaching this question allows the testing of whether states follow the understanding of 'missing persons' under IHL treaty law. The second and third questions address two issues that are crucial for families of missing persons that are not addressed in IHL: (2) How is the legal status of the missing person regulated? (3) Are family members provided with measures of reparation and/or assistance? This approach reveals that states rarely apply the IHL understanding of 'missing persons' and predominantly exceed IHL by addressing some of the identified shortcomings. It further shows that states provide families of missing persons either with reparation measures - in cases of human rights violations - or, less often, with measures of assistance in post-conflict situations.

Keywords: missing persons, enforced disappearance, families of missing persons, IHL implementation, legal status of missing persons, reparation, measures of assistance, socio-economic needs

\section{INTRODUCTION}

When persons go missing, their families are deeply affected. They suffer from not knowing what has happened to their loved ones, whether they are alive or dead. ${ }^{1}$ As many persons go missing in the context of an armed conflict or occupation, both treaty-based and customary international humanitarian law (IHL) contain provisions concerning missing persons, which aim primarily at prevention. ${ }^{2}$ The main objective of this article is to test how states implement IHL with regard

\footnotetext{
* PhD; Polish Academy of Sciences (Poland); Hertie School, (Germany); g.baranowska@inp.pan.pl. The research for this article was funded by the Polish National Science Centre ('State Obligations with regard to Missing and Disappeared Persons under International Law', grant agreement 2019/35/D/HS5/03700). An earlier version of the article was presented during the 15th Annual Minerva Conference on International Humanitarian Law, and I would like to thank participants for comments received during the conference. Additionally, I would like to thank Yuval Shany, Gloria Gaggioli, Nasia Hadjigeorgiou, Alessandra La Vaccara, Aleksandra Gliszczyńska-Grabias, Katarzyna SękowskaKozłowska, Łukasz Szoszkiewicz, Joanna Grygiel, as well as the anonymous reviewers for helpful comments.

${ }^{1}$ Simon Robins, Families of the Missing: A Test for Contemporary Approaches to Transitional Justice (Routledge 2013); Pauline Boss, Ambiguous Loss: Learning to Live with Unresolved Grief (Harvard University Press 2000); Iosif Kovras, Grassroots Activism and the Evolution of Transitional Justice: Families of the Disappeared (Cambridge University Press 2017).

${ }^{2}$ See Section 3 for relevant IHL treaty law. For relevant rules in customary IHL see Jean-Marie Henckaerts and Louise Doswald-Beck, Customary International Humanitarian Law, Vol I: Rules (International Committee of the Red Cross (ICRC) and Cambridge University Press 2005, rev'd 2009) (ICRC Study), rule 98 ('Enforced
} 
to the families of missing persons. I briefly present relevant IHL provisions that show shortcomings with regard to families of missing persons and compare them with relevant human rights law applicable in cases of enforced disappearance, namely the secret deprivation of liberty committed by state authorities. ${ }^{3}$ Against this background I then analyse national legislation collected in the National Implementation Database of the International Committee of the Red Cross (ICRC) in its section titled 'The Missing and Their Families'. ${ }^{4}$ This approach reveals that states do not use the term 'missing persons' in the way in which it is applied in IHL treaty law and predominantly exceed IHL by addressing some of the identified shortcomings.

I selected the ICRC database for two reasons. Firstly, although not exhaustive, the database provides a comprehensive overview of how states implement IHL and illustrates possible approaches to incorporating IHL. It includes laws on missing persons and their families in 100 pieces of legislation ${ }^{5}$ from 38 states in various parts of the world, including the states that are most affected. ${ }^{6}$ Secondly, as the database aims at sharing information on implementation measures, the list of countries in the database could be considered as most likely to follow the IHL approach with regard to missing persons and their families. However, the domestic solutions analysed show that states go beyond IHL and take another approach to the term 'missing persons', giving it a broader application than is found in IHL treaty law.

After a preliminary analysis of the legislation included in the ICRC database, I examined the legislation listed regarding three selected questions of particular relevance for families of missing persons. Firstly, I analysed who is considered a 'missing person' under each law. While IHL treaty law applies to those who became missing during an armed conflict (see Section 2), most acts included in the ICRC database are not restricted to such instances. The laws that refer to persons missing in connection with an armed conflict are mainly limited to certain conflicts or time frames. Moreover, many of the laws apply to forcibly disappeared persons. ${ }^{7}$ The second question is concerned with regulating the legal status of the missing person, which is crucial for that person's family, in particular because of practical concerns such as welfare,

disappearance is prohibited') 340; rule 105 ('Family life must be respected as far as possible') 379; rule 112 ('Whenever circumstances permit, and particularly after an engagement, each party to the conflict must, without delay, take all possible measures to search for, collect and evacuate the dead without adverse distinction') 406; rule 116 ('With a view to the identification of the dead, each party to the conflict must record all available information prior to disposal and mark the location of the graves') 417; and rule 117 ('Each party to the conflict must take all feasible measures to account for persons reported missing as a result of armed conflict and must provide their family members with any information it has on their fate') 421 .

${ }^{3}$ See Section 2.1 .

${ }^{4}$ ICRC, 'The Missing and Their Families', National Implementation of IHL Database, https://ihl-databases.icrc. org/applic/ihl/ihl-nat.nsf/vwLawsByCountry.xsp?xp_topicSelected=GVAL-992BUF (ICRC Database). The ICRC database seeks to share information on implementation measures collected by the ICRC Advisory Service and provided by states.

${ }^{5}$ The analysis does not include case law listed in the database.

${ }^{6}$ There is no data that allows a detailed comparison of the number of missing persons in different countries (which, among other factors, is because of underreporting in certain regions). However, the database includes legislation from most relevant countries; see introduction to Section 5 for further information.

${ }^{7}$ eg, two Argentinian laws on enforced disappearances: Ley núm. 24.321 [junio 8 de 1994]: desaparición forzada de personas; Ley núm. 24.411 [diciembre 28 de 1994]: desaparición forzada de personas. For further examples see Section 5 . 
inheritance, marriage and parental rights. There is no obligation under IHL to take such steps, but much of the legislation in the ICRC database contains such regulations. ${ }^{8}$ In the analysis I discuss and assess the different perspectives taken by states in this respect. The last issue relates to granting families of missing persons measures of reparation and assistance, for which IHL also does not provide. The analysis of the ICRC database allowed me to distinguish between two groups of laws: (i) laws that deal with victims of human rights violations and provide measures of reparation; and (ii) laws that cover persons missing from a particular armed conflict, which provide measures of assistance to those in need. Thus, in practice, families of missing persons are provided with reparation measures only in cases of human rights violation, and measures of assistance - sometimes - in post-conflict situations. Those two forms of measure are fundamentally different: one is a right related to the harm suffered, while the other is a form of social benefit. ${ }^{9}$ While states could apply both forms of benefit, my analysis revealed that they apply only one.

The next section of the article introduces terminology. The third section elaborates IHL provisions applicable to families of missing persons, while the fourth section presents relevant provisions from the International Convention for the Protection of All Persons from Enforced Disappearance (ICPPED), and how they are interpreted within the framework of enforced disappearances. ${ }^{10}$ The fifth section contains an analysis of domestic legislation from 'The Missing and Their Families' section of ICRC National Implementation Database - including consideration of the three questions presented above: (i) Who is considered a missing person? (ii) What is the legal status of missing persons? (iii) What are the rights of families to receive measures of reparation and assistance? This is followed by conclusions in the sixth section.

\section{TERMinOLOGY}

\subsection{Missing Persons}

'Missing persons' are not defined in IHL, but in IHL treaty law the term applies to those who went missing in connection with armed conflict or occupation. This means that their relatives, the powers on which they depend (if they are combatants), or the country of which they are nationals or in whose territory they reside (if they are civilians) have no information about their fate. ${ }^{11}$

\footnotetext{
${ }^{8}$ eg, Ley 19.123 que crea la Corporación Nacional de Reparación y Reconciliación (Chile). For more examples see Section 5.3.

${ }^{9}$ See also Section 4 on how this difference is present in the framework of enforced disappearances.

${ }^{10}$ International Convention for the Protection of All Persons from Enforced Disappearance (entered into force 23 December 2010) 2716 UNTS 3 (ICPPED).

${ }^{11}$ Marco Sassòli, International Humanitarian Law: Rules, Controversies, and Solutions to Problems Arising in Warfare (Edward Elgar 2019) 339; Anna Petrig, 'eSearch for Missing Persons' in Andrew Clapham, Paola Gaeta and Marco Sassòli (eds), The 1949 Geneva Conventions: A Commentary (Oxford University Press 2015) 258. See also Yves Sandoz, Christophe Swinarski and Bruno Zimmermann, Commentary on the Additional Protocols of 8 June 1977 to the Geneva Conventions of 12 August 1949 (ICRC and Martinus Nijhoff 1987) 351, para 1229 (Commentary to Additional Protocols (1987)) (explaining how 'missing' is understood in
} 
Outside IHL, the term 'missing persons' is often used in a much broader way, encompassing all persons whose whereabouts remain unknown, not only in connection with armed conflicts. The ICRC applies the term to individuals about whom their families have no news, who have been reported missing, or to any other situation of a person going missing that might require action by a neutral and independent body. ${ }^{12}$ The ICRC approach is of particular relevance as it is crucial in developing IHL and, as such, the way in which it interprets and uses IHL terms has a potential impact on other stakeholders. ${ }^{13}$ The particular significance of the ICRC in the subject matter analysed also stems from the fact that it has shaped the practice of searching for missing persons, as it has a long history of engaging with missing persons and their families, including restoring family links.

In 2009 the ICRC adopted the 'Guiding Principles/Model Law on the Missing'. ${ }^{14}$ While the principles were adopted 'for legislating the situation of persons missing as a result of armed conflict or internal violence' - thus fitting the approach of IHL treaty law to the term - they define 'missing persons' in a much broader manner. According to the Model Law, a 'missing person' is someone whose whereabouts are unknown and who - based on reliable information - has been reported missing in accordance with national legislation in connection with armed conflict and internal violence, natural catastrophes, or any other situation that could require the intervention of a state authority. ${ }^{15}$ Thus, the proposed definition reflects the humanitarian approach taken by the ICRC, which is not only the organisation that is crucial in guarding and developing IHL but is also a major humanitarian and relief organisation.

Some missing persons are forcibly disappeared. While IHL treaties do not deal with enforced disappearance, IHL customary law prohibits the practice in both international and non-international armed conflict. ${ }^{16}$ The ICPPED defines 'enforced disappearance' as: ${ }^{17}$

Additional Protocol 1 (n 27). States (and sometimes non-state parties) also conclude agreements in which they address missing persons; for an overview of such agreements see Alessandra La Vaccara, When the Conflict Ends, While Uncertainty Continues: Accounting for Missing Persons between War and Peace in International Law (Hart 2019) 264-71.

${ }^{12}$ ICRC, 'Q\&A: The ICRC's Engagement on the Missing and Their Families' (2017) 99 International Review of the Red Cross 535, 536.

${ }^{13}$ For more on the ICRC and its influence on the development of IHL, see Robin Geiß, Andreas Zimmermann and Stefanie Haumer (eds), Humanizing the Laws of War: The Red Cross and the Development of International Humanitarian Law (Cambridge University Press 2017).

${ }^{14}$ ICRC, Advisory Service on International Humanitarian Law, 'Guiding Principles/Model Law on the Missing', 28 Feb. 2009, https://www.icrc.org/en/document/guiding-principles-model-law-missing-model-law.

15 ibid art 2.

${ }^{16}$ See Henckaerts and Doswald-Beck (n 2) rule 98 'Enforced disappearance is prohibited'.

${ }^{17}$ See ICPPED (n 10) art 2. As regards the mutual influences between IHL and international human rights law in the context of enforced disappearances, see Gloria Gaggioli, 'The Prohibition of Enforced Disappearances: A Meaningful Example of a Partial Merger between Human Rights Law and International Humanitarian Law' in Robert Kolb and Gloria Gaggioli (eds), Research Handbook on Human Rights and Humanitarian Law (Edward Elgar 2013) 320, 321-22 (how international human rights law has been able to influence IHL by creating a non-derogable right and giving birth to customary rules applicable in armed conflict) and 325-26 (how IHL has influenced international human rights law beyond the right to know). Gaggioli states that in the context of enforced disappearances the formation of customary international law 'provides a fine example of the dynamic interplay between' international human rights law and IHL. For a perspective on missing persons in international human rights law and IHL see also La Vaccara (n 11). 
arrest, detention, abduction or any other form of deprivation of liberty by agents of the State or by persons or groups of persons acting with the authorisation, support or acquiescence of the State, followed by a refusal to acknowledge the deprivation of liberty or by concealment of the fate or whereabouts of the disappeared person, which place such a person outside the protection of the law.

A person can be considered both a forcibly disappeared person and a missing person if the deprivation of liberty is conducted by state authorities during both an international and noninternational armed conflict. ${ }^{18}$ However, this is not always the case: enforced disappearances not related to an armed conflict will not be subject to IHL treaty law. Additionally, disappearances during contemporary armed conflicts are often conducted by non-state actors. These victims would be considered missing persons under IHL but not forcibly disappeared persons under international human rights law, as long as there was no authorisation, support or acquiescence by the state in respect of the actions of the non-state actor. While such disappearances are not enforced disappearances per se, states still have obligations under the ICPPED to investigate such acts and bring those responsible to justice. ${ }^{19}$ Furthermore, states have due diligence obligations to protect human rights 'against acts committed by private persons or entities that would impair the enjoyment' of human rights, which also includes disappearances by non-state actors. ${ }^{20}$

\footnotetext{
${ }^{18}$ While originally the term 'enforced disappearance' was used predominantly in the context of non-international armed conflict only (see, eg, Gloria Gaggioli (n 17) 322), this is changing. The Inter-American Convention on the Forced Disappearance of Persons (entered into force 28 March 1996) 68 OAS 1429, adopted in 1994, states explicitly that it does not apply during international armed conflict governed by the Geneva Conventions and their Additional Protocols (art 15), while the ICPPED (n 10), adopted in 2006, does not contain such a clause, stating only that the Convention 'is without prejudice to the provisions of International Humanitarian Law' (art 43). The UN Working Group on Enforced or Involuntary Disappearances initially did not accept requests concerning disappearances that happened during armed conflict, but this practice was changed in 2012. On the Working Group, see Olivier de Frouville, 'Working Out a Working Group: A View from a Former Working Group Member' in Aoife Nolan, Rosa Freedman and Therese Murphy (eds), The United Nations Special Procedures System (Brill Nijhoff 2017) 223, 235.

${ }_{19}$ ICPPED (n 10) art 3 . There is a fine line between a disappearance committed by non-state actors, which would fall under art 3 ICPPED, and 'acquiescence' by the state, which would make the situation an enforced disappearance. No legal document clarifies this matter. The UN Working Group on Enforced or Involuntary Disappearances added in its annual report published in June 2019 an interesting voice to the discussion about disappearances by non-state actors: 'For a number of years, the Working Group has been receiving information about increasing instances of abductions carried out by non-State actors, which may be tantamount to acts of enforced disappearances. In light of its humanitarian mandate and the fact that the victims of these acts do not have any remedy to address their plight, the Working Group has decided to document cases concerning enforced or involuntary disappearances allegedly perpetrated by non-State actors that exercise effective control and/or government-like functions over a territory': Human Rights Committee, Report of the Working Group on Enforced or Involuntary Disappearances (30 July 2019), UN Doc A/HRC/42/40, para 94.

${ }^{20}$ UN Human Rights Committee, General Comment No 31: The Nature of the Legal Obligations Imposed on State Parties to the Covenant (29 March 2004), UN Doc CCPR/C/21/Rev.1/Add.13, para 8. See also the following judgments of the Inter-American Court of Human Rights (IACtHR) on due diligence: IACtHR, Velásquez-Rodríguez v Honduras, Judgment (Merits), 29 June 1988, Ser C, No 4, para 172; IACtHR, González and Others ('Cotton Field') v Mexico, Judgment (Preliminary Objection, Merits, Reparations, and Costs), 16 November 2009, paras 283-84. For an analysis see La Vaccara (n 11) 208-21, and Lene Guercke, 'State Responsibility for a Failure to Prevent Violations of the Right to Life by Organized Criminal Groups: Disappearances in Mexico' (2021) 21 Human Rights Law Review 329.
} 
Enforced disappearances are also addressed in international criminal law, and within this framework they are defined more broadly than within international human rights law as they can be perpetrated also by political organisations. ${ }^{21}$ If someone disappears during an armed conflict at the hands of a political organisation as part of an attack that constitutes a crime against humanity, such an individual would be a missing person under IHL and a forcibly disappeared person under international criminal law, while his or her disappearance would not be considered an enforced disappearance under international human rights law. ${ }^{22}$

Consequently, there is a difference in the definition of 'enforced disappearances' in international human rights law and criminal law, while 'missing persons' are not defined in any area of international law. This complicates the categorisation of persons who have disappeared and indicating the obligations that apply in each case. At the same time, the categorisation does not deprive missing persons of all protection: due diligence obligations under international human rights law will apply irrespective of how the person is categorised, and the protective framework under IHL applies to all circumstances arising from an armed conflict.

State obligations under international law differ depending on the circumstances of the disappearance, the applied areas of international law, and - in the case of an armed conflict - its type (international or non-international). ${ }^{23}$ However, the families left behind have the same experiences: they do not know whether their loved ones are alive or dead; they search for

\footnotetext{
${ }^{21}$ The Rome Statute of the International Criminal Court ((entered into force 1 July 2002) 2187 UNTS 90) (ICC Statute), art 7(i), includes enforced disappearance as one of the acts which could be categorised as a crime against humanity; see ICC, Situation in the Republic of Burundi, ICC 01/17-X, Pre-Trial Chamber III, 25 October 2017, paras 117-29 (in which the Chamber found that there was a reasonable basis to believe that the crime of enforced disappearance was committed by the Burundian security forces as part of a widespread and systematic attack against the Burundian civilian population). For more on the interpretation of the term 'political organisation', particularly with regard to the ICC decision in the 2010 Kenya case, ICC, Situation in the Republic of Kenya, ICC-01/09, March 2010, see Irena Giorgou, 'State Involvement in the Perpetration of Enforced Disappearance and the Rome Statute' (2013) 11 Journal of International Criminal Justice 1001. Limiting enforced disappearances in international human rights law to acts requiring state involvement has been criticised also from an IHL perspective (Gaggioli (n 17) 328); for the arguments for including non-state actors as perpetrators of enforced disappearances, see Giorgou (ibid 1011-15). See also the justification of the human rights approach to enforced disappearances in Tulio Scovazzi and Gabriella Citroni, The Struggle Against Enforced Disappearance and the 2007 United Nations Convention (Leiden 2007) 278-83.

${ }^{22}$ To address these terminological problems, Jeremy Sarkin argues for using the same procedures for both forcibly disappeared and missing persons: Jeremy Sarkin, 'The Need to Deal with All Missing Persons Including Those Missing as a Result of Armed Conflict, Disaster, Migration, Human Trafficking and Human Rights Violations (Including Enforced Disappearances) in International and Domestic Law and Processes' (2015) 8 Inter-American and European Human Rights Journal 116, 140-41; Jeremy Sarkin, 'Why Victimology Should Focus on All Victims, Including All Missing and Disappeared Persons' (2019) 25 International Review of Victimology 249.

${ }^{23}$ See Section 3.2 for IHL obligations applicable in international armed conflict. Additional Protocol II to the Geneva Convention does not contain specific provisions on missing persons that apply during non-international armed conflict. However, according to art 8 of Additional Protocol II, all possible measures shall be taken to search for and collect the wounded, sick and shipwrecked, and the dead should be searched for. Those measures should be taken whenever circumstances permit and particularly after an engagement: Protocol Additional to the Geneva Conventions of 12 August 1949, and relating to the Protection of Victims of Non-International Armed Conflicts (entered into force 7 December 1978) 1125 UNTS 609.
} 
them; they go through phases of ambiguous loss: ${ }^{24}$ and they often face economic hardship, in particular, if the missing person was the main breadwinner. The legal uncertainty also causes practical challenges related to welfare, inheritance and marriage, among other things. The suffering of family members can be further exacerbated, for example, if state authorities refuse to conduct a search, do so in an ineffective manner, or deny the disappearance.

There are benefits in adopting an umbrella definition, as proposed by the ICRC in the Model Law, which covers all persons whose whereabouts remain unknown: it allows all families to file cases concerning their missing relatives, irrespective of causes. This is crucial, in particular, when the circumstances of the disappearance are unknown - for example, if the family is unsure whether the person went missing because of an armed conflict. Introducing different categories for families, depending on the circumstances of the disappearance, can lead to a situation in which they cannot effectively use existing mechanisms. ${ }^{25}$ However, with regard to persons missing as a result of an armed conflict and forcibly disappeared persons, there are particular obligations under international law. When providing such a broad definition, a state needs to secure the rights of families of missing persons who fall within those two groups: families of forcibly disappeared persons, for example, have a right to reparation. A state, of course, may also choose to provide those rights for families of other missing persons, such as those missing because of natural disasters.

\subsection{FAMILIES}

I use the term 'family' in this article with regard to all those close to the missing person who suffer as a direct result of the disappearance. ${ }^{26}$ As explained in the 1987 ICRC commentary to Additional Protocol 1 to the Geneva Conventions (Additional Protocol 1), ${ }^{27}$ from a humanitarian perspective, 'families' in the protocol include not only blood relatives and legal ties but also personal and emotional ties. ${ }^{28}$ Within the enforced disappearance framework 'any individual who has suffered harm as the direct result of an enforced disappearance' is a victim of that enforced disappearance. ${ }^{29}$ While this phrasing is potentially broader than the term 'family', when approaching the term in such a broad way as proposed by the ICRC commentary to Additional Protocol 1, both IHL and the ICPPED cover all individuals who have suffered as a direct result of the missing/disappearance. ${ }^{30}$

\footnotetext{
${ }^{24}$ Pauline Boss, 'Ambiguous Loss Research, Theory, and Practice: Reflections after 9/11' (2004) 66 Journal of Marriage and Family 553-54, 561-62. The author defines 'ambiguous loss' as 'a situation of unclear loss resulting from not knowing whether a loved one is dead or alive, absent or present'.

${ }^{25}$ Gabriella Citroni, 'The First Attempts in Mexico and Central America to Address the Phenomenon of Missing and Disappeared Migrants' (2017) 99 International Review of the Red Cross, 735, 741-42.

${ }^{26}$ This is based on the ICPPED approach to who is considered a victim of an enforced disappearance: ICPPED (n 10) art 24(1).

${ }^{27}$ Protocol Additional to the Geneva Conventions of 12 August 1949 relating to the Protection of Victims of International Armed Conflicts (entered into force 7 December 1978) 1125 UNTS 3 (Additional Protocol I).

${ }^{28}$ See Commentary to Additional Protocols (1987) (n 11) 346, para 1215.

${ }^{29}$ ICPPED (n 10) art 24(1).

${ }^{30}$ Additional Protocol I (n 27) art 34(2)(c), relating to the request for the return of remains, speaks of the 'next-of-kin', which appears to be narrower than the term 'relative' used in arts 32 and 34.2(a); see Commentary to Additional Protocols (1987) (n 11) 375, para 1344.
} 


\section{Families of Missing Persons in IHL Treaties}

\subsection{Geneva Conventions}

The Geneva Conventions contain provisions that aim to prevent persons from going missing and to establish their fate when they do. Such measures are clearly beneficial for families of missing persons. For example, states should establish Information Bureaus to receive and transmit information about protected persons, ${ }^{31}$ which serve to identify such persons and advise their next of kin. ${ }^{32}$ Furthermore, provisions aimed at identifying and registering the wounded and dead ${ }^{33}$ are relevant for families of missing persons as they lead to establishing the fate of the missing who have died. Collecting and forwarding personal valuables can also lead to identifying missing persons. ${ }^{34}$ Prisoners of war are specifically entitled to contact with their families, which also prevents their being deemed missing by their families. ${ }^{35}$

The Fourth Geneva Convention (GC IV), on the protection of civilian populations, contains slightly stronger protection of family life that is relevant for families of missing persons. All persons in the territory of a party to a conflict or in an occupied territory are enabled to give and receive news of a personal nature to and from family members. ${ }^{36}$ Parties to a conflict shall further facilitate enquiries of families dispersed by war, with the aim of renewing contact with one another and, if possible, meeting each other. ${ }^{37} \mathrm{GC}$ IV further specifies that protected persons are entitled 'to respect for $\ldots$ their family rights'. ${ }^{38}$ Parties shall also ensure that families are not separated when undertaking transfer or evacuation, ${ }^{39}$ and during internment. ${ }^{40}$

\footnotetext{
31 'Protected persons' are 'those who, at a given moment and in any manner whatsoever, find themselves, in case of a conflict or occupation, in the hands of persons a Party to the conflict or Occupying Power of which they are not nationals': Geneva Convention (IV) relative to the Protection of Civilian Persons in Time of War (entered into force 21 October 1950) 75 UNTS 287 (GC IV), art 4.

${ }^{32}$ GC IV, ibid arts 136-140. For similar provisions with regard to prisoners of war, see Geneva Convention (III) relative to the Treatment of Prisoners of War (entered into force 21 October 1950) 75 UNTS 135 (GC III), arts 122 and 123 .

${ }^{33}$ Geneva Convention (I) for the Amelioration of the Condition of the Wounded and Sick in Armed Forces in the Field (entered into force 21 October 1950) 75 UNTS 31 (GC I), arts 15-17; Geneva Convention (II) for the Amelioration of the Condition of the Wounded, Sick and Shipwrecked Members of Armed Forces in the Field (entered into force 21 October 1950) 75 UNTS 85 (GC II), arts 19-20; GC III (n 32) art 120.

${ }^{34} \mathrm{GC}$ IV (n 31) art 139; GC III (n 32) art 122(9).

${ }^{35} \mathrm{GC}$ III (n 32) art 48 (informing the person's next-of-kin in due time about the person's transfer); GC III, arts 71, 72 (providing them with particular measures to reach their family if they have been without news for a long time). Providing POWs with identity cards also can be regarded as a preventive measure.

${ }^{36} \mathrm{GC}$ IV (n 31) art 25.

37 ibid art 26.

${ }^{38} \mathrm{ibid}$ art 27(1). According to the 1958 ICRC Commentary to GC IV, this specifically includes maintaining ties between parents and children, as well as restoring them in the event that they were broken by wartime events: Oscar Uhler and Henri Coursier, Geneva Convention relative to the Protection of Civilian Persons in Time of War: Commentary (Geneva 1958).

${ }^{39} \mathrm{GC}$ IV (n 31) art 49(3).

${ }^{40} \mathrm{ibid}$ art 82(3). See La Vaccara (n 11) 111 for a table of relevant IHL provisions that are applicable before, during and in the aftermath of an armed conflict (both international and non-international armed conflicts).
} 
The Geneva Conventions therefore contain provisions aimed at preventing persons from going missing, including ensuring that the dead are accounted for. However, the search for missing persons is considerably less developed in the Geneva Conventions. Lastly, families are not at the centre of a search and are not specifically provided with any rights.

\subsection{Additional Protocol 1 to the Geneva Conventions (Articles 32-34)}

Rights of families of persons going missing during international armed conflict were strengthened significantly through the adoption of Additional Protocol 1 . This explicitly places families of missing persons in the picture as it states that, in implementing its provisions concerning missing and dead persons, parties to an international armed conflict and humanitarian organisations 'shall be prompted mainly by the right of families to know the fate of their relatives' ${ }^{41}$ This provision does not create a new right; as stated in Additional Protocol 1, it is a 'general principle'. ${ }^{42}$ Commentators have stated that the provision 'constitutes a sort of preamble to Section III'. ${ }^{43}$ As the Commentary to Additional Protocol 1 states, the provision was written with the intention for each search to be founded on 'a concern for the interests of families and to spare them emotional suffering as far as possible'. ${ }^{44}$ However, using the term 'right' has been strongly objected to by some states, arguing that it should be considered a 'need' rather than a 'right'. While eventually Article 32 does include the 'right of families', the content of this obligation is not easy to determine. ${ }^{45}$

Articles 33 and 34 contain detailed provisions concerning the search for the missing, identification of the dead and maintenance of grave sites with regard to persons who would not receive more favourable consideration under the Geneva Conventions and Additional Protocol 1. Certain obligations concerning missing persons apply also after the end of hostilities. For example, parties to the conflict are required to search for persons reported missing 'as soon as circumstances permit, and at the latest from the end of active hostilities' ${ }^{46}$ Furthermore, as some provisions from this section deal with conflict results, they apply also to the conflict results that occurred before the entry into force of Additional Protocol 1 - as long as they still need to and can reasonably be made the object of legal regulation. ${ }^{47}$

Families clearly have the right to receive information about missing persons when their fate has been established, and they have the right of access to grave sites in the event of the death of

\footnotetext{
${ }^{41}$ Additional Protocol I (n 27) art 32.

42 Title of art 32 in Additional Protocol I (n 27). It is the only provision titled 'General Principle' in the Additional Protocols.

${ }^{43}$ Michael Bothe, Karl Josef Partsch and Waldemar A Solf (eds), New Rules for Victims of Armed Conflicts: Commentary on the Two 1977 Protocols Additional to the Geneva Conventions of 1949 (2nd edn, Brill Nijhoff 2013) 196.

${ }^{44}$ See Commentary to Additional Protocols (1987) (n 11) 347, para 1217. Similarly, arts 33(4) and 34(2)(a) were intended to benefit the families of missing persons (ibid 362, para 1281; 371, para 1322).

45 ibid $343-44$, paras $1196-98 ; 345$, paras $1211-12$. For more on the discussions about the right to truth in this context see also Gaggioli (n 17) 321-22.

${ }^{46}$ Additional Protocol I (n 27) art 33(1).

${ }^{47}$ Bothe, Partsch and Solf (n 43) 194-95. As an example, the drafters of the Commentary point to the situation where grave sites exist but agreements under art 34.2 have not yet been concluded.
} 
the missing person. Additional Protocol 1 addresses the need for families of missing persons to establish their fate. However, the relevant provisions in Additional Protocol 1 have one significant shortcoming: they do not oblige families to be kept informed of the progress of the search. At the same time, Additional Protocol 1 does not provide for additional measures to make daily life easier for family members of missing persons, such as regulating the legal status of the families and providing them with measures of assistance. ${ }^{48}$ Such actions are of utmost importance for families who often struggle with economic hardship and the legal consequences of a missing family member, including those affecting inheritance, property and parental rights. ${ }^{49}$

\section{Families of Forcibly Disappeared Persons in the ICPPED}

The ICPPED is the first treaty that explicitly recognises families of forcibly disappeared persons as victims of enforced disappearance and provides them with a number of rights. ${ }^{50}$ The rights granted to families in the ICPPED address the two above-mentioned shortcomings in IHL. The Convention requires states to provide them with reparation and prompt, fair and adequate compensation. ${ }^{51}$ Reparation for victims of enforced disappearance cover material and moral damages and, where appropriate, other forms of reparation such as restitution, rehabilitation, satisfaction (including restoration of dignity and reputation) and guarantees of non-repetition. ${ }^{52}$ Furthermore, according to the ICPPED, while continuing the investigation until the fate of the disappeared person has been clarified, states are to take appropriate steps with regard to the legal position of forcibly disappeared persons whose fate has not been clarified and that of their relatives, in fields such as social welfare, financial matters, family law and property rights..$^{53}$

\footnotetext{
${ }^{48}$ The GCs and Additional Protocol I do not contain measures of reparation for families of missing persons, which results from the fact that they apply to persons who became missing irrespective of a violation of IHL.

${ }^{49}$ See, eg, Robins (n 1). On the specific effects that disappearances have on women see, eg, Polly Dewhirst and Amrita Kapur, 'The Disappeared and Invisible: Revealing the Enduring Impact of Enforced Disappearance on Women', International Center for Transitional Justice, 15 March 2015, https://www.ictj.org/sites/default/files/ ICTJ-Global-Gender-Disappearances-2015.pdf; Human Rights Council, General Comment on Women Affected by Enforced Disappearances Adopted by the Working Group on Enforced or Involuntary Disappearances at its Ninety-eighth Session (31 October-9 November 2012), UN Doc A/HRC/WGEID/98/2.

${ }^{50}$ Families of forcibly disappeared persons have themselves been found to be victims of human rights violations by international courts. On the development of the case law of the European Court of Human Rights (ECtHR) see Tamar Feldman, 'Indirect Victims, Direct Injury: Recognizing Relatives as Victims under the European Human Rights System' (2009) 1 European Human Rights Law Review 50; Grażyna Baranowska, 'Families of Disappeared Persons in the Jurisprudence of the European Court of Human Rights' (2018) 5 European Human Rights Law Review 505; for a broader perspective of the approach by both the ECtHR and the IACtHR to family members see also Ruth Rubio-Marín, Clara Sandoval and Catalina Díaz, 'Repairing Family Members: Gross Human Rights Violations and Communities of Harm' in Ruth Rubio-Marín (ed), The Gender of Reparations: Unsettling Sexual Hierarchies while Redressing Human Rights Violations (Cambridge University Press 2009) 215.

${ }^{51}$ ICPPED (n 10) art 24(4).

52 ibid art 24(5).

${ }_{53} \mathrm{ibid}$ art 24(6). Families of forcibly disappeared persons also have the right to know the truth about the circumstances of the enforced disappearance, the progress and results of the investigation, and the fate of the forcibly disappeared person (art 24(2)). Victims of enforced disappearance should be guaranteed the right to freely form and participate in organisations and associations concerned with attempting to establish the circumstances
} 
Thus, the ICPPED obliges states to provide families of forcibly disappeared persons with measures of reparation but it does not require states to provide measures of assistance. The dire socio-economic situation of families of forcibly disappeared persons is not recognised explicitly in the ICPPED. However, the UN Committee on Enforced Disappearances - a body of independent experts that monitors the implementation of the ICPPED by state parties - has raised this issue in its concluding observations to country reports. In particular, the Committee, in 2016, expressed its concern about 'the absence of a State law on access to social benefits for relatives of disappeared persons'. ${ }^{54}$ However, this is not an issue often raised by the Committee. ${ }^{55}$ The UN Working Group on Enforced or Involuntary Disappearances - a UN special procedure also addressing this issue - has been far more outspoken in that states should take measures to provide relatives of forcibly disappeared persons with social security benefits. ${ }^{56}$ In its study on enforced disappearances and economic, social and cultural rights, the Working Group clearly distinguished between measures of reparation and measures of assistance, the latter of which are 'provided to the families to cope with the dire consequences of the absence of the main breadwinner'. ${ }^{57}$ However, this critical distinction has not yet been approached so clearly by the UN Committee on Enforced Disappearances.

The ICPPED clearly provides more rights for families of forcibly disappeared persons than IHL does for families of missing persons. ${ }^{58}$ There are several reasons for this discrepancy. Recognising the rights of families of missing and disappeared persons is a relatively new trend and is therefore clearly present in the ICPPED, adopted in 2006, but is missing in the IHL treaties adopted in 1949 (the Geneva Conventions) and 1977 (the Additional Protocols), which merely require states to search for missing persons and provide families with information. Moreover, an enforced disappearance is a human rights violation, while a person can go missing during an armed conflict or occupation without any violation of IHL. This justifies stronger obligations for states, which are to provide measures of reparation in cases of enforced disappearance. Not including the obligation to clarify the legal position of families in IHL might have had

of enforced disappearances and the fate of forcibly disappeared persons, and to assist victims of enforced disappearance (art 24(7)).

${ }^{54}$ UN Committee on Enforced Disappearances, Concluding Observations on the Report submitted by Bosnia and Herzegovina under Article 29(1) of the Convention (3 November 2016), UN Doc CED/C/BIH/CO/1, para 37.

${ }^{55}$ For other examples when the Committee has referred to social benefits, see Committee on Enforced Disappearances, Concluding Observations on the Report submitted by Chile under Article 29(1) of the Convention (8 May 2019), UN Doc CED/C/CHL/CO/1, para 24; Committee on Enforced Disappearances, Concluding Observations on the Report submitted by Serbia under Article 29(1) of the Convention (16 March 2015), UN Doc CED/C/SRB/CO/1.

${ }^{56}$ UN General Assembly, Report of the Working Group on Enforced or Involuntary Disappearances, Study on Enforced or Involuntary Disappearances and Economic, Social and Cultural Rights (9 July 2015), UN Doc A/HRC/30/38/Add.5, paras 48, 60 and 71 .

${ }^{57} \mathrm{ibid}$ para 69 . The difference between measures of reparation and measures of assistance was also acknowledged in the 2013 report on compensation: Human Rights Council, Report of the Working Group on Enforced or Involuntary Disappearances (28 January 2013), UN Doc A/HRC/22/45, paras 56-68; see, in particular, para 50. ${ }^{58}$ There are areas in which IHL provides more detailed regulations than the framework addressing enforced disappearances, in particular, in the area of the identification and preservation of missing persons' remains; see articles referenced in Section 3.1. 
another reason: families of missing persons under IHL are assumed to be in a state other than that where the person went missing (in general, in their country of origin). However, this may not be the case in many instances as their families may be in the same state as a result of migration or occupation.

\section{The IMPLEMENTATION OF IHL}

The implementation of IHL is examined on the basis of the analysis of the section on 'The Missing and Their Families' of the ICRC National Implementation Database. It includes over 100 legislative instruments from 38 states representing geographically diverse regions, with the majority of states in Europe and South America. ${ }^{59}$ The high number of laws from South America is especially telling, as the region has been at the forefront of addressing enforced disappearances, in both the regional Inter-American human rights system and in national systems. The very term 'enforced disappearance' is a translation of the Spanish notion 'desaparición for$z a d a$, coined to describe the serious human rights violations that happened in the 1960s and 1970s in various South American countries. However, enforced disappearances have been and remain a worldwide phenomenon not limited to this region of the world. The Inter-American human rights system adopted the first treaty on enforced disappearance and many crucial cases concerning such disappearances. ${ }^{60}$ Thus, the high number of South American states in the database exemplifies their influence on the development of the enforced disappearance framework on missing persons.

The states listed in the database have very different experiences with missing persons, ranging from huge numbers of currently missing persons (Mexico) to large numbers of unresolved cases of missing persons stemming from past conflicts (Bosnia and Herzegovina, Spain), to just a few cases (Belgium). Thus, the database gives a comprehensive view of how states with different situations approach missing persons. It also includes the majority of the states where persons went missing and continue to be missing in a widespread manner. For example, the database includes laws from Argentina and Chile, where enforced disappearances were widespread in the 1970s and triggered the development of a framework to address enforced disappearances. Mexico is another crucial state, in particular because of the high number of disappearances

\footnotetext{
${ }^{59}$ ICRC Database (n 4): Europe (16): Albania, Armenia, Azerbaijan, Belarus, Belgium, Bosnia and Herzegovina, Croatia, France, Georgia, Germany, Montenegro, Portugal, Russian Federation, Spain, Switzerland, Ukraine; South America (11): Argentina, Bolivia, Brazil, Chile, Colombia, El Salvador, Guatemala, Mexico, Paraguay, Peru, Uruguay. The database includes only five examples from Africa (Algeria, Egypt, Mali, Nigeria, Zimbabwe) and three from Asia (India, Kyrgyzstan, Sri Lanka; however, the Russian Federation along with three South Caucasian states are included in the European count), as well as Australia, Canada and the United States.

${ }^{60}$ Ariel Dulitzky, 'The Latin-American Flavor of Enforced Disappearances' (2019) 19 Chicago Journal of International Law 423, 444-45. While the Inter-American Convention on the Forced Disappearance of Persons (1994) was the first treaty on enforced disappearances, it was preceded by the UN Declaration on the Protection of All Persons from Enforced Disappearance (28 February 1992), UN Doc E/CN.4/RES/1992/29.
} 
that continue to happen. ${ }^{61}$ The database also includes Bosnia and Herzegovina, where widespread disappearances occurred during the war in the $1990 \mathrm{~s},{ }^{62}$ as well as Sri Lanka, which remains a state with one of the highest number of outstanding cases of missing persons. ${ }^{63}$

The nature of the legislation listed varies and the vast majority of laws are not limited to persons who go missing in the context of an armed conflict. It includes instances of GC implementation $^{64}$ and the establishment of national information bureaus as provided for in the GCs. ${ }^{65}$ The laws include provisions from both criminal ${ }^{66}$ and civil codes. ${ }^{67}$ Several acts with the aim of establishing truth or search commissions are also to be found in the database. ${ }^{68}$ Some laws apply to selected groups of missing persons, such as children missing in the context of an armed conflict ${ }^{69}$ and missing women. ${ }^{70}$ A substantial part of the legislation listed in the database refers specifically to enforced disappearances, although in some cases the crime is defined more broadly than it is in the ICPPED as it also covers disappearances by non-state actors. ${ }^{71}$

The analysis of legislative instruments in the ICRC database brought up three core questions of particular relevance for families of missing persons: (1) Who is considered a missing person under each law? Approaching this question allows the testing of whether states follow the understanding of 'missing persons' in IHL treaty law. The second and third questions address two

\footnotetext{
${ }^{61}$ In the opinion of the UN Committee on Enforced Disappearances, the situation in Mexico reached a level that justifies a visit under art 33 ICPPED (n 10): Report of the Committee on Enforced Disappearances (4 May and 7 September 2020), UN Doc A/75/56, paras 70-71, see also paras 44-48.

${ }^{62}$ This also led to the creation of a number of international bodies specifically for post-Yugoslav countries with the aim of assisting families of missing persons, among other things: Grażyna Baranowska, Rights of Families of Disappeared Persons: How International Bodies Address the Needs of Families of Disappeared Persons in Europe (Intersentia 2021) 133-72, 199-208.

${ }^{63} \mathrm{~A}$ country not included in the database - although it has a widespread problem - is Iraq. For an overview of missing persons throughout the world, see Human Rights Council, Annual Reports by the ICRC and the UN Working Group on Enforced or Involuntary Disappearances, https://www.ohchr.org/en/issues/disappearances/ pages/annual.aspx.

${ }^{64}$ Ligj nr. 7624, datë 14.10.1992, për aderimin në Protokollet shtesë të Konventës së Gjenevës të vitit 1949 (Albania).

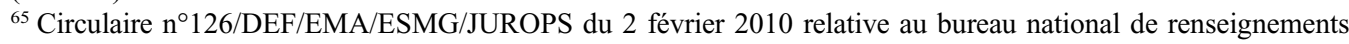
sur les prisonniers de guerre, 2010 (France); Decreto no. 5.684 por el cual se asigna a la Dirección de Asuntos Jurídicos, Derechos Humanos y Derecho Internacional Humanitario del Ministerio de Defensa Nacional, las funciones de Oficina Nacional de Información en Caso de Conflicto Armado, de conformidad a lo previsto en los Convenios III y IV de Ginebra de 1949 y sus Protocolos Adicionales (Paraguay).

${ }^{66}$ eg, Ley 26.679 (Delitos contra la libertad) modifícanse el Código Penal y el Código Procesal Penal de la Nación, 2011 (Argentina).

${ }^{67}$ eg, Code Civil, 1804 (Belgium); Decreto con Fuerza de Ley 1, fija texti refundido, coordinado y sistemazido del Codigo Civil (Chile).

${ }^{68}$ eg, Decreto 187/83 sobre la Comision Nacional sobre la Desaparicion de Personas, 1983 (Argentina); Acuerdo Gubernativo No 264-2006 (Guatemala).

${ }^{69}$ Decreto núm. 45 [5 de octubre de 2004]: créase la Comisión Interinstitucional de Búsqueda de Niños y Niñas Desaparecidos a Consecuencia del Conflicto Armado en El Salvador.

${ }^{70}$ Decreto No 8-2016 mediante el cual se decreta la Ley de Búsqueda Inmediata de Mujeres Desaparecidas (Guatemala).

${ }^{71}$ eg, two Argentinian laws on enforced disappearances (Ley núm. 24.321 (n 7); Ley núm. 24.411 (n 7)). The law setting up the truth commission in Bolivia (Law $\mathrm{N}^{\circ} 879$ de la Comisión de la Verdad) creates a truth commission to investigate 'enforced disappearances, murders, tortures, arbitrary detentions and sexual violence that happened between 1964 and 1982; Decreto $N^{\circ} 8.767$ que promulga a Convenção Internacional para a Proteção de Todas as Pessoas contra o Desaparecimento Forçado (Brazil).
} 
issues crucial for families of missing persons that are not addressed in IHL: (2) How is the legal status of the missing person regulated? (3) Are family members provided with measures of reparation or assistance? The subsection addressing each question presents relevant legislation and discusses challenges that arise. Where applicable, each part also indicates relevant international standards and recommendations.

\subsection{Who are the 'Missing Persons'}

The laws collected in the ICRC database apply to different groups of missing person. Some define the term specifically, while others only allow such a reading from the context. Most of the laws that relate to persons missing in armed conflict are limited to certain conflicts. For example, the 2004 law of Bosnia and Herzegovina applies to persons about whom their families 'have no information and/or are reported missing on the basis of reliable information as a consequence of the armed conflict that happened on the territory of the former SFRY' between 30 April 1991 and 14 February 1996. ${ }^{72}$ The Spanish Law of 2007 concerns persons who disappeared in violent circumstances during the Civil War (1936-39) or during subsequent political repressions and whose whereabouts remain unknown. ${ }^{73}$ The law adopted in Brazil in 1995 applies to the forcibly disappeared - thus not all missing persons - between September 1961 and October $1988 .^{74}$ A similar approach is taken by the 2009 law of Chile, which applies to cases of enforced disappearance that occurred between September 1973 and March $1990 .^{75}$ A 2004 law in Peru applies to enforced disappearances that occurred during political violence between 1980 and 2000. However, the Peruvian law does not differentiate between disappearances committed by state and non-state actors and, as such, has a broader scope than enforced disappearances as defined in the ICPPED. ${ }^{76}$ Similarly, the 2017 Mexican law applies both to victims of enforced disappearance and to persons whose disappearances were caused by 'private individuals' ${ }^{77}$ It has a yet broader scope as it is not limited to a specific time frame.

\footnotetext{
${ }^{72}$ Zakon o nestalim osobama [21.10.2004.] (Bosnia and Herzegovina), art 2.1.

${ }^{73}$ Ley 52/2007, de 26 de diciembre, por la que se reconocen y amplían derechos y se establecen medidas en favor de quienes padecieron persecución o violencia durante la guerra civil y la dictadura 2007 (Spain), art 11.

${ }^{74}$ Lei no. 9.140, de 4 de dezembro de 1995 - Lei dos Desaparecidos (Brazil), art 1.

${ }^{75}$ Ley n 20377 Sobre Declaración de Ausencia por Desaparición Forzada de Personas, 25 de Agosto 2009 (Chile), art 1.

${ }^{76}$ Ley No 28413 que regula la ausencia por desaparición forzada durante el periodo 1980-2000 (2005) (Peru), art 3; Resolucion Defensorial $\mathrm{N}^{\circ}$ 04-2005-DP, aprueban Directiva ${ }^{\circ}$ 01-2005-DP, Normas para la verificacion de la situacion de ausencia por desaparicion forzada y para la expedicion de la constancia correspondiente (2005) (Peru), art 1.

${ }^{77}$ Ley General en materia de personas desaparecidas (2017) (Mexico), art. 2. The ICRC database translates the Law as 'General Law on Missing Persons', but 'General Law on Disappeared Persons' appears to be better suited. This is how the law is usually translated into English, and it more accurately reflects the content of the law. The law establishes two crimes: (i) enforced disappearances, and (ii) disappearances committed by individuals (art 2.II). It distinguishes between two groups of persons whose whereabouts remain unknown: (i) those whose absence is presumed to be related to the commission of a crime ('persona sesaparecida', art 4.XV); and (ii) those whose absence has been reported to the authorities but is not related to a crime ('persona no localizada', art 4.XVI). While the law is aimed primarily at the first group, it also partly covers the second group. For more on the law and disappearances by non-state actors in Mexico, see Guercke (n 20).
} 
Choosing a specific time frame for the application of the term 'missing persons' may lead to excluding selected groups of persons who are missing. While Cyprus is not one of the countries listed in the ICRC database, it is a telling example. Overall, 2,002 persons disappeared during the armed conflict between Greek and Turkish Cypriots (1963-64) and the Turkish invasion of the island (1974). During the first period, predominantly Turkish Cypriots were disappeared and Greek Cypriots during the second. ${ }^{78}$ The Republic of Cyprus subsequently adopted a law concerning missing persons, which applied to those missing 'due to the Turkish invasion', which excludes the vast majority of the missing Turkish Cypriots. ${ }^{79}$ As the Cypriot law makes clear, state authorities can practically exclude entire groups of missing persons. This can occur, for example, by limiting the law to certain dates (of disappearance and reporting), nationality or ethnicity of the missing, place of residence of the missing and their family members. Applying laws on missing persons only to selected groups or times is not forbidden by international law. However, as such regulations can easily be discriminatory, they should be carefully scrutinised and assessed. This is particularly important because the consequence of not being considered a missing person under a particular law results in the law not applying to the family of that person and depriving the family members of possible support.

A law adopted in Sri Lanka exemplifies a broad approach towards missing persons. The 2016 law defines missing persons as those whose fate or whereabouts are reasonably believed to be unknown as a result of (i) the conflict that occurred in the Northern and Eastern Provinces or its aftermath, or is a missing-in-action member of the police or armed forces; (ii) political unrest or civil disturbance; (iii) enforced disappearances. ${ }^{80}$ Thus, it covers persons who went missing in one specific conflict, as well as during political unrest and civil disturbances, and relates to all forcibly disappeared persons. While this still might exclude some persons, such as those who became missing in events preceding the conflict, it seems to cover the vast majority of missing persons.

The 2018 Ukrainian law on the missing proposes yet another perspective. It defines missing persons as all whose whereabouts are unknown at the time of the request for a search, and introduces two additional categories of missing person, the first of which is those 'missing in connection with armed conflict'. Within this category fall all who disappeared in the area of armed conflict during military service or under any other circumstances that prove that the person was present in this area. Thus, it includes persons missing in the context of both international and non-international armed conflict and does not differentiate between civilians and military. The presence in the area of armed conflict is conclusive to be considered a person missing in

\footnotetext{
${ }^{78}$ Christalla Yakinthou, 'The Quiet Deflation of Den Xehno? Changes in the Greek Cypriot Communal Narrative on the Missing Persons in Cyprus' (2008) 20(1) The Cyprus Review 15. On missing persons in Cyprus see also Nasia Hadjigeorgiou, 'Truth and Closure in a Frozen Conflict: An Assessment of the Committee on Missing Persons in Cyprus' (2021) 55 Israel Law Review, https://doi.org/10.1017/S0021223721000121.

${ }^{79}$ Iosif Kovras and Neophytos Loizides, 'Delaying Truth Recovery for Missing Persons' (2011) 17 Nations and Nationalism 520, 526.

${ }^{80}$ Office on Missing Persons (Establishment, Administration and Discharge of Functions) Act, No. 14 of 2016 (Sri Lanka), art 27.
} 
connection with armed conflict. The second category, 'persons missing as a result of special circumstances', includes all who disappeared in the context of armed conflict - therefore covering all in the first category - as well as those who disappeared as a result of military actions, riots within the state, or in connection with natural or man-made disasters or other events that could cause the mass death of people. ${ }^{81}$ This definition is very close to that proposed by the ICRC in the Guiding Principles/Model Law on the Missing, ${ }^{82}$ but adds the requirement of mass deaths, which may significantly narrow the applicability of the law to 'other events'. The major provisions in the law - that is, relating to the legal status of the missing person, rights of missing persons and their families, and the search - apply to all missing persons. ${ }^{83}$ However, the law provides for additional measures with regard to those missing as a result of special circumstances (second category): (i) a permanent advisory body to the cabinet of ministers with a strong emphasis on those who disappeared during the post-2014 conflict in South-East Ukraine ${ }^{84}$ and (ii) a unified register of those persons. ${ }^{85}$ The two measures are fairly detailed and show the particular attention paid to this group of missing persons. The disappeared from the post-2014 conflict in South-East Ukraine were particularly relevant during the drafting of the law because of their significant numbers. ${ }^{86}$

The US laws listed in the ICRC database use the term 'missing persons' with regard to members of the armed forces on active duty or US citizens who are civilian officers or employees of the Department of Defense who become 'involuntarily absent as a result of a hostile action or under circumstances suggesting that the involuntary absence is a result of a hostile action and whose status is undetermined or who is unaccounted for' ${ }^{87}$ This, therefore, is a narrower understanding than that of the IHL treaties as it does not include all civilians who went missing during armed conflicts.

The law adopted in 1993 in Azerbaijan is an example of an entirely different approach to missing persons and their families. It designates as a 'martyr' anyone who 'died for the independence, sovereignty and territorial integrity of the Republic of Azerbaijan, went missing on the

\footnotetext{
${ }^{81}$ Law of Ukraine, 'On the Legal Status of the Missing Person' (2018), art 1.

${ }^{82}$ ICRC (n 14) art 2: any person who is missing 'in connection with armed conflict, internal violence, natural catastrophes, or any other situation that would require the intervention of state authority'.

${ }^{83}$ Law of Ukraine (n 81) arts 2-8, 17-22.

${ }^{84}$ ibid arts 10-11 (in particular the territory of Donetsk and Luhansk regions).

85 ibid arts $12-16$.

${ }^{86}$ Baranowska (n 62) 24-25.

${ }^{87}$ Armed Forces, US Code, Title 10, Ch 76 (Missing Persons Act), (2001) US, art C. The other US enactments in the ICRC database also concern members of armed forces: Department of Defense, Instruction No. 1000.1, 16 April 2012 (incorporating Change 1, 9 June 2014); Department of Defense, Instruction No. 1300.18, 8 January 2008 (incorporating Change 1, 14 August 2009). The regulations foresee a procedure whereby each person is declared to be in one of the following four categories: missing, deserted, absent without leave, or dead: Missing Persons Act, para 1503(d)3. For the developments of US politics and regulations in this area see Michael Allen, Until the Last Man Comes Home: POWs, MIAs, and the Unending Vietnam War (University of North Carolina Press 2009); Michael R Dolski, 'When X Doesn't Mark the Spot: Historical Investigation and Identifying Remains from the Korean War' in Derek Congram (ed), Missing Persons: Multidisciplinary Perspectives on the Disappeared (Canadian Scholar's Press 2016) 137.
} 
grounds of military operations and considered dead in accordance with legislation' ${ }^{88}$ Thus, the law creates one category for two groups of persons: those who died, and those missing who are presumed to have died in military operations.

The equal treatment of the dead and the missing also appears in other legislation. According to the Code of Person and the Family adopted in Mali in 2011, missing persons are those who became missing following circumstances likely to endanger their life and whose remains were not found. ${ }^{89}$ Thus, only those about whom there is a very high probability that they have died can be considered missing.

While IHL treaty law and international human rights law do not contain an obligation to consider the missing person alive, this is an approach recommended by both frameworks. For example, according to the ICRC Guiding Principles/Model Law on the Missing, 'missing persons should be presumed to be alive until their fate has been ascertained'.$^{90}$ Similarly, the guiding principles for the search for disappeared persons of the UN Committee on Enforced Disappearances requires states to conduct the search under the presumption that they are alive. ${ }^{91}$ Consequently, domestic legislators should refrain from treating missing persons as dead for as long as they reasonably can be considered to be alive. ${ }^{92}$

The laws listed in the database do not approach the term 'missing persons' in the way in which IHL applies it, meaning those who went missing in connection with armed conflict or occupation. When relating to conflict-related missing persons, the laws do not apply to all missing persons but limit their application to a specific time frame or conflict. At the same time, the laws also do not apply the term 'missing persons' to such a broad group as does the ICRC that is, to all persons reported missing. Exceptions appear in a number of civil codes listed in the database, which contain provisions concerning the effect of a missing person on assets and family. ${ }^{93}$

\subsection{The Legal Status of a Missing Person}

To ease the practical problems a family faces after a person goes missing, it is crucial to regulate the legal status of that person. There are essentially two forms in which this can take place: (i) a

\footnotetext{
${ }^{88}$ Law of the Republic of Azerbaijan on Perpetuating the Memory of Martyrs and Benefits of Families of Martyrs (Azerbaijan), art 1.

${ }^{89}$ Loi no 2011-087 du 30 décembre 2011 portant Code des personnes et de la famille (Mali), art 76.

${ }^{90}$ ICRC (n 14) 16. This includes continuing the search even after the missing person is declared dead, if the remains of the person are not found.

${ }^{91}$ UN Committee on Enforced Disappearances, Guiding Principles for the Search for Disappeared Persons (8 May 2019), UN Doc CED/C/7.

${ }^{92}$ However, it is not entirely clear for how long a person should reasonably be considered alive. Some families hold on to the hope of their loved ones returning after decades without any information; suffice it to consider how the opening of borders between the northern and southern parts of Cyprus in 2003 awakened the hopes of some of the families that their loved ones might still return when their relatives went missing 30 to 40 years earlier: Öncel Polili, 'Kuzey Kibris’ta kayip kişiler ve ailelerinin insan haklari' (2012) 9 Kibrisli Türk İnsan Haklari Vakfi Yayinlari, Appendix 2.

${ }^{93}$ eg, Code Civil (Belgium) (n 67); Decreto con Fuerza de Ley 1 (Chile) (67).
} 
declaration of absence ${ }^{94}$ (or certificates on the status of missing persons); and (ii) a declaration of death (or presumption of death). Both forms appear in the enactments analysed.

The practice of declaring as dead persons who went missing during an armed conflict precedes the Geneva Conventions and relevant international human rights law. In particular, states adopted such regulations with regard to persons who did not return from the Second World War. For example, a Belgian law, adopted in 1948, established a procedure to declare such missing persons dead, including concentration camp detainees. ${ }^{95}$

As a result of the various approaches to missing persons presented in the previous section, some states provide the possibility of obtaining a declaration of absence in respect only of some missing persons. In Bosnia and Herzegovina, for example, only families of persons missing in the context of the armed conflict between 30 April 1991 and 14 February 1996 are entitled to receive certificates of the status of a missing person. ${ }^{96}$ This leaves persons whose family members became missing in other contexts or time frames without the ability to regulate their status. Furthermore, they are deprived of measures of assistance where provided for by the law in question.

A declaration of absence is provided for in the majority of laws adopted in Latin American countries. These include Chile (with regard to enforced disappearances between September 1973 and March 199097), Colombia (for victims of enforced disappearance and other forms of involuntary disappearance ${ }^{98}$ ), Uruguay (all missing persons ${ }^{99}$ ), and Mexico (all missing persons in the Civil Code ${ }^{100}$ and specifically disappeared persons according to the General Law on Disappeared Persons ${ }^{101}$ ). In most of these instances there is a procedure to declare presumption of death after a set amount of time. For example, the Civil Codes of Spain ${ }^{102}$ and Peru ${ }^{103}$ provide for a judicial declaration of absence followed by the presumption of death. The 2016 Sri Lankan law allows for the issuing of certificates of absence for two years, after which the relatives issued with the document decide whether they wish to extend the period by two years, apply for a death certificate, or cancel the certificate of absence. ${ }^{104}$ The Kyrgyz Civil Code establishes that after the whereabouts

\footnotetext{
${ }^{94}$ For more on the 'declaration of absence' see Gabriella Citroni, 'The Pitfalls of Regulating the Legal Status of Disappeared Persons through Declaration of Death' (2014) 12 Journal of International Criminal Justice 787.

${ }^{95}$ In addition to persons missing as a result of armed conflict the law also explicitly included persons who disappeared in concentration gaps or have been arrested and then disappeared: Loi du 20 août 1948 relative aux déclarations de décès et de présomption de décès et à la transcription et la rectification administrative de certains actes de décès, art 4 (Belgium). On the post-Second World War Convention on the Declaration of Death of Missing Persons, which aimed to manage the legal positions of thousands of families who were waiting for answers, see also La Vaccara (n 11) 51-52. For examples of laws from the nineteenth century on accounting for missing persons and family reunification of soldiers, see La Vaccara, ibid 40-42.

${ }^{96}$ Zakon o nestalim osobama (Bosnia and Herzegovina) (n 72) art 29.

${ }^{97}$ Ley n ${ }^{\circ} 20377$ (Chile) (n 75) art 1.

${ }^{98}$ Ley 1531 de 2012 (mayo 23) por medio de la cual se crea la acción de declaración de ausencia por desaparición forzada y otras formas de desaparición involuntaria y sus efectos civiles (Colombia).

${ }^{99}$ Código civil (Actualizado al 26 de febrero de 2010) (Uruguay), art 61.

${ }^{100}$ Codigo Civil Federal, 1928 (as of 2013) (Mexico), arts 669-678.

${ }^{101}$ Ley General en materia de personas desaparecidas (Mexico) (n 77) art 142.

${ }^{102}$ Spanish Civil Code (1990 as of 2012), arts 181-93.

${ }^{103}$ Decreto Legislativo ${ }^{\circ} 295$, Codigo Civil (1984) (Peru), arts 49-66.

${ }^{104}$ Registration of Deaths (Temporary Provisions) (Amendment) Act, No. 16 of 2016 (Sri Lanka), art 8k(2).
} 
of a citizen have been unknown for three years, a court may declare the person dead. If the person went missing under life-threating circumstances, this can be done after six months. Persons missing in military action can be declared deceased by a court two years after the conclusion of such action. ${ }^{105}$ According to the 2018 Ukrainian law, missing persons may be declared dead in the manner prescribed by law, but the search continues until their whereabouts, place of burial or whereabouts of their remains are determined. ${ }^{106}$ Thus, adopting a specific period after which a missing person is (or may) be declared dead is a common practice.

Mexico serves as an interesting example as its Civil Code and General Law on Disappeared Persons provide for different solutions. According to the Civil Code, the standard time period in which to declare a missing person dead is six years. The period is shortened to two years when the disappearance occurred in a war or a shipwreck, and to six months when the disappearance is the consequence of fire, explosion, earthquake, plane or train crash, and there is a well-founded presumption that the missing person was at the scene of the accident. ${ }^{107}$ By contrast, the Mexican General Law on Disappeared Persons foresees two events that will terminate the declaration: the disappeared person re-appears, or has been found dead. ${ }^{108}$ Similarly, there are two different procedures in Peru: one included in the 1984 Civil Code (judicial declaration of absence, followed by the presumption of death); ${ }^{109}$ the other for enforced disappearance that occurred during political violence between 1980 and 2000. ${ }^{110}$

Some of the laws analysed do not envision the possibility of declaring a person absent, only a declaration of death. For example, Canadian provinces adopted laws that allow only for declaring missing persons dead. ${ }^{111}$ The 2011 Malian law prescribes a 'judicial declaration of death'. ${ }^{112}$ In Egypt, missing persons are presumed dead after at least 15 days from a ship sinking or a plane crash. Members of armed forces reported missing during military operations are presumed dead after one year. ${ }^{113}$

Under IHL treaty law there are no obligations to introduce procedures for a declaration of absence, but the ICRC Guiding Principles/Model Law on the Missing state that it is 'desirable to provide for an interim period of absence before a death certificate is issued' ${ }^{114}$ The international human rights framework has been more explicit in this regard; in particular, the

\footnotetext{
${ }^{105}$ Civil Code of the Kyrgyz Republic (1996), arts 79-80.

${ }^{106}$ Law of Ukraine (n 81) art 4.4.

${ }^{107}$ Codigo Civil Federal (Mexico) (n 100) art 705; for more on the presumption of death of a disappeared person, see arts 706-14.

${ }^{108}$ Ley General en materia de personas desaparecidas (Mexico) (n 77) art 148.

${ }^{109}$ Codigo Civil (1984) (Peru) (n 103) arts 49-66.

${ }^{110}$ Ley No 28413 (Peru) (n 76) art 3; Resolucion Defensorial Nº4-2005-DP (Peru) (n 76) art. 1.

${ }^{111}$ See, eg, Presumption of Death Act. R.S., c 354, s 1 (consolidated to 18 April 2012): An Act Respecting Presumption of Death (Nova Scotia, Canada); Presumption of Death Act, R.S.N.L. 1990, c p-20: An Act to Provide for the Making of Orders Declaring that Persons Named in the Orders are Presumed to be Dead (Newfoundland and Labrador, Canada).

${ }^{112}$ Loi no 2011-087 (Mali) (n 89) arts 76-83 and 190; see art 83.1 on reappearance.

${ }^{113}$ Law No 2 of 2006 amending some provisions of Act No 25 of 1929 concerning certain personal status provisions (Egypt), art 1.

${ }^{114}$ ICRC (n 14) 16; see also art 8 'Recognition of absence' and commentary, 19-20.
} 
UN Human Rights Committee has taken a strong stand on the issue. In deciding cases brought by families from Bosnia and Herzegovina requesting recognition of their missing relatives as dead in order to obtain social allowances, the Committee found that such a practice constituted inhuman and degrading treatment. In cases where compensation was conditioned on declaring the missing person dead, where there was no certainty as to their fate the investigations that aimed to clarify the circumstances of the missing were still ongoing. ${ }^{15}$ This leaves for states the possibility of adopting procedures to establish the death of the missing person after the investigation has been terminated, even if the fate of the person and relevant circumstances have not been clarified.

Considering the ambiguous loss experienced by families of missing persons along with issues of parental and property rights, it is clearly beneficial to regulate the status of a missing person in the declaration of absence form, which - as follows from the analysis - is a common practice. However, according to the vast majority of laws, the missing person is to be declared dead after a certain period. As families often hope for the reappearance of their loved ones even decades after they have become missing, they might prefer not to declare their missing family members dead. This is achievable: states should adopt laws that allow for prolonging the status of absence (as in Sri Lanka). As most civil codes foresee different effects flowing from the declaration of absence and death, this would also need to be addressed. For example, according to the Argentinian law, a declaration of absence issued as a result of enforced disappearances and a declaration of absence with the presumption of death have the same effects. ${ }^{116}$ So far, such solutions have been introduced in relation to enforced disappearances but they could equally be adopted for broader groups of missing persons.

\subsection{The Rights of Families to Measures of Reparation or Assistance}

Not all of the laws provide for measures of reparation or assistance to families of missing persons. Those that do can be divided into two groups: (i) those relating to victims of human rights

\footnotetext{
${ }^{115}$ Human Rights Committee (HRC), Communication No 1997/2010, Views Adopted by the Committee at its 110th Session (10-18 March 2014), UN Doc CCPR/C/110/D/1997/2010 (Rizvanovic $v$ Bosnia and Herzegovina), para 9.6. In the decisions issued a year earlier it found that a very similar case was a violation of the obligation to provide an effective remedy: HRC, Communication Nos 1917/2009, 1918/2009, 1925/ 2009, 1953/2010, Views Adopted by the Committee at its $107^{\text {th }}$ Session (10-28 March 2014), UN Doc. CCPR/C/107/D/1917/2009, 1918/2009, 1925/2209, 1953/2010 (Fatima Prutina and Others $v$ Bosnia and Herzegovina), para 9.6. The line of reasoning from Rizvanovic (violation of the prohibition of inhuman and degrading treatment) was subsequently repeated in a number of cases: HRC, Communication No 1956/2010, Views Adopted by the Committee at its 111th Session (7-25 July 2014), UN Doc CCPR/C/111/D/1956/2010 (Duric v Bosnia and Herzegovina), para 9.8; HRC, Communication No 2003/2010, Views Adopted by the Committee at its 111th Session (7-25 July 2014), UN Doc CCPR/C/111/D/2003/2010 (Selimovic and Others v Bosnia and Herzegovina), para 12.7; HRC, Communication No 2028/2011, Views Adopted by the Committee at its 113th Session (16 March-2 April 2015), UN Doc CCPR/C/113/D/2050/2011 (Ičić and Ičić v Bosnia and Herzegovina), para 9.7. On the case law see also Manfred Nowak, 'Enforced Disappearances in Bosnia and Herzegovina: Recent Developments in International Jurisprudence' in Fazil Sağlam and others (eds), Prof. Dr. Rona Aybay' a Armağan (2 CILT Takım 2014) 2766-68.

${ }^{116}$ Ley núm. 24.321 (Argentina) (n 7) art 3.
} 
violations (primarily enforced disappearances); (ii) those that address persons missing in the context of a particular armed conflict (or specifically relating to missing members of armed forces). ${ }^{117}$ The second group, therefore, follows the IHL treaty approach to missing persons but limits it to a specific armed conflict: those who went missing in connection with an armed conflict or occupation.

Within the first group of these legal responses, Chile provided in 1992 for monthly reparation pensions for victims of human rights violation and their families, including families of forcibly disappeared persons. ${ }^{118}$ Reparation for families in the form of monetary compensation is also seen in a 1995 Brazilian law, which is intended to take into consideration, inter alia, the age of the forcibly disappeared person. ${ }^{119}$ The 1994 Argentinian law provides for compensation for the legal successors of the forcibly disappeared (who have died or are still missing). The benefit provided to them is equal to that payable in respect of those who have died as a result of actions of armed forces. ${ }^{120}$ Similarly, according to the 2013 Mexican law, families are entitled to measures of compensation and satisfaction. ${ }^{121}$ Furthermore, it contains the imprescriptible right to know the truth and receive information about the human rights violations or crimes that directly affected them, including the circumstances in which they occurred and, if applicable, the fate of the missing persons and the whereabouts of their remains. ${ }^{122}$ These rights apply almost equally to families of persons whose disappearance is attributed to the state and to non-state actors. The only difference is that state authorities must provide reparation to families of forcibly disappeared persons and 'compensate in a subsidiary way' those whose relatives' disappearances were caused by non-state actors. ${ }^{123}$

The 2010 Colombian law grants families of forcibly disappeared persons resources necessary to pay for the funeral and travel expenses during the entire process of delivering the human remains. The families are also provided with psychosocial care throughout the process. ${ }^{124}$ The Colombian law differs from the aforementioned laws in that it restricts help to expenses connected with burying the deceased missing person. This specific aspect is covered by other laws, although not in so much detail. In Mexico, for example, families of persons who disappeared as a result of human rights violations or crimes have the right to be present during exhumation, be informed of the procedures and progress of the investigation, and receive the human remains. ${ }^{125}$

\footnotetext{
${ }^{117}$ Which responds to how La Vaccara (n 11) 221-34 categorises the duty to investigate: (i) the 'accountabilitydriven' duty regarding human rights violations, including enforced disappearances; and (ii) the humanitarian in nature duty to search for persons reported missing during a conflict.

${ }^{118}$ Ley 19.123 (Chile) (n 8).

${ }^{119}$ Lei no. 9.140 (Brazil) (n 74) art 11.

${ }^{120}$ Ley núm. 24.411 (Argentina) (n 7) arts 1-2.

${ }^{121}$ Decreto por el que se expide la Ley General de Víctimas (2013) (Mexico), arts 70-72.

122 ibid art 23.

${ }^{123}$ Ley General en materia de personas desaparecidas (Mexico) (n 77) art 152 (see also arts 139, 150-51).

${ }^{124}$ Ley 1408 de 2010 (agosto 20) por la cual se rinde homenaje a las víctimas del delito de desaparición forzada y se dictan medidas para su localización e identificación (Colombia), arts 7-8.

${ }^{125}$ Ley General de Víctimas (Mexico) (n 121) art 25.
} 
The second group of laws are those that provide measures of assistance to families of persons missing in the context of an armed conflict. According to the 2004 law in Bosnia and Herzegovina, families of missing persons have the right to know the fate and whereabouts of their missing relative, or the circumstances and cause of death (if applicable), and to receive their mortal remains if their location is known. ${ }^{126}$ Those who were supported by the missing person and are in need of support are entitled to monthly financial support, ${ }^{127}$ while children of missing persons have priority in realising the right to education. ${ }^{128}$ The 1993 Azerbaijani law - which includes persons missing from military operations and sees them as 'martyrs' - provides for a number of assistance measures for the family; these measures include pensions, welfare payments for children, various allowances, and exemption from tuition fees at state institutions. ${ }^{129}$ However, in contrast to the other laws, it does not provide for any measures to establish the fate of missing persons.

The law of Sri Lanka applies both to persons from the first group (all forcibly disappeared) and the second group (missing as a result of the conflict in the Northern and Eastern Provinces or civil disturbances). Family members who have received a certificate of absence may use it to apply for benefits under any social welfare scheme. ${ }^{130}$

Some family members of the missing are granted a survivor's pension under the Ukrainian law of 2018. This is provided for dependent incapacitated persons, all children, as well as parents or spouses, even those who were not dependent on the missing person, as long as they lost their livelihood because of the disappearance. ${ }^{131}$ While the law concerns all those whose whereabouts are unknown, it was adopted during the time when a significant number of persons disappeared in connection with the post-2014 conflict in South-East Ukraine, who are mentioned explicitly in several places in the law. There is thus no doubt that the law was inspired by an armed conflict.

The right to financial assistance and social benefits for relatives of missing persons was explicitly included in the ICRC Guiding Principles/Model Law on the Missing. ${ }^{132}$ The document proposes that authorities should assess and recognise the specific financial and social needs and provide monthly financial assistance for those who were materially supported by a missing person or found themselves in need of material support following the disappearance. States clearly have not (yet) implemented this proposal.

The featured laws reflect the obligations arising from international law: measures of reparation must be provided in cases of human rights violations. As such, they do not seem to recognise the particularly dire situation that all families of missing persons face and provide them with measures of assistance. Some states have adopted laws that provide support for families of

\footnotetext{
${ }^{126}$ Zakon o nestalim osobama (Bosnia and Herzegovina) (n 72) art 3.

127 ibid arts 2.9, 11. The realisation of the law has been criticised by the UN Committee on Enforced Disappearances: CED (n 54) para 37.

${ }^{128}$ Zakon o nestalim osobama (Bosnia and Herzegovina) (n 72) art 18.

${ }^{129}$ Law of the Republic of Azerbaijan (n 88) art 3.

${ }^{130}$ Registration of Deaths (Temporary Provisions) (Amendment) Act (Sri Lanka) (n 104) art 8J(1).

${ }^{131}$ Law of Ukraine (n 81) art 6.4.

${ }^{132}$ ICRC (n 14) art 10.
} 
persons who became missing in particular conflicts (both international and non-international). While the analysis demonstrates that states adopt either measures of reparation or measures of assistance, the two forms can and should coexist. ${ }^{133}$ Social assistance does not prejudice the obligation of the state to provide reparation for victims of human rights violations, and vice versa. However, the analysis reveals that states opt for one form of measure only - if they consider implementation of the measures at all.

\section{Conclusions}

'Missing persons' is not a defined term. While IHL applies to those missing in connection with an armed conflict or occupation, in other contexts it is often applied with regard to all persons whose whereabouts remain unknown, which is also the approach proposed in the ICRC Model Law. Adopting a broad umbrella definition has a potential advantage for families, as it allows them to file cases concerning their missing relatives irrespective of the causes. However, when using such a broad definition of missing persons, states must secure the obligations provided under IHL with regard to persons missing as a result of armed conflict and under international human rights law with regard to forcibly disappeared persons.

IHL contains provisions aimed at preventing persons from going missing; however, it does not strongly address the rights of families of missing persons. These have been specifically addressed in Article 32 of Additional Protocol 1, which stipulates that parties to an international armed conflict and humanitarian organisations 'shall be prompted mainly by the right of families to know the fate of their relatives', although the contents of this obligation are vague and thus not determined.

This article has identified two main shortcomings of Additional Protocol 1 with regard to families of missing persons. Firstly, there are no obligations for states to regulate the legal status of a missing person, such as in the form of a declaration of absence. Secondly, Additional Protocol 1 does not contain any provisions requiring states to provide families of missing persons with any form of material assistance. Those two issues are addressed partly within the enforced disappearances framework: the ICPPED contains both the obligation to provide families with measures of reparation (but not measures of assistance) and the obligation to act with regard to the legal situation of forcibly disappeared persons. ${ }^{134}$ The article has identified three possible reasons for the stronger obligations with regard to families of forcibly disappeared persons than for families of persons who became missing in the context of an armed conflict. The first is that recognition of the rights of families (or, more broadly, so-called 'indirect victims') is a relatively new phenomenon and Additional Protocol 1 was adopted much earlier (1977) than the ICPPED (2006). Secondly, an enforced disappearance is a human rights violation, while persons can go missing during armed conflicts or occupations without any IHL violation. Thirdly, under IHL,

\footnotetext{
${ }^{133}$ HRC (n 57) paras 46-68; see, in particular, para 50.

${ }^{134}$ ICPPED (n 10) arts 24(4) and (6).
} 
families of missing persons are assumed to be in another state than the state in which the person went missing.

The analysis of the ICRC database proves that when states adopt laws relating to missing and forcibly disappeared persons, they do not always differentiate clearly between the two legal frameworks, which exemplifies the convergence of obligations derived from IHL and international human rights law. The laws examined do not approach 'missing persons' as all those who went missing in connection with an armed conflict (the approach of IHL treaty law) or all who have been reported missing (the ICRC approach). ${ }^{135}$ When applying their laws to armed conflicts, states select particular time frames, which can lead to discrimination or the exclusion of some missing persons, depending on which time frame the authorities choose. Some states categorise as missing only those persons who are assumed to be dead. Lastly, many of the acts mentioned in the ICRC database explicitly refer to cases of enforced disappearance. Some of the laws have a wider approach than the ICPPED to enforced disappearance, as they also include persons whose disappearances were caused by non-state actors.

Many of the laws contained in the ICRC database include provisions regulating the legal status of missing persons. This takes the form of either a declaration of absence (also named differently, such as 'certificates on the status of missing persons') or a declaration of death (or presumption of death). Most of the laws analysed lead to a declaration of death after a certain time. The ICRC recommends that states provide for an interim period of absence before issuing a death certificate. Requiring families of missing persons to declare their missing relative dead to obtain social allowances during ongoing investigations has been found to constitute inhuman and degrading treatment. Thus, states should adopt measures that regulate the legal status in the form of a declaration of absence, at least as an interim solution. Among the laws included in the ICRC database, only a few include solutions that allow families to prolong the status of absence, which, I argue, is beneficial for families who do not wish to declare their loved ones dead even after a prolonged time. Many families of missing persons experience ambiguous loss and hope for the reappearance of their loved ones even decades after they went missing; thus, those families do not want to receive a declaration of death, even after an interim period.

While provisions that regulate the status of missing persons are widespread, legislation that includes measures of assistance or reparation for families is much less prevalent. The laws that provide such support can be divided in two groups: (i) those that apply to victims of human rights violations (predominantly enforced disappearances); and (ii) those that deal with persons missing in the context of a specific armed conflict (or, specifically, with missing members of armed forces). The solutions adopted differ widely, but we may notice tendencies in each group. The first group primarily provides measures of reparation, while the second - smaller - group mostly offers measures of assistance to family members in need. This reflects the obligations under international law, as victims of human rights violations are entitled to reparation and compensation. However, the

\footnotetext{
${ }^{135}$ With the exception of a number of civil codes listed in the database, which contain provisions that address the effect that a person going missing has on his or her assets and family: see, eg, Code Civil (Belgium) (n 67); Decreto con Fuerza de Ley 1 (Chile) (n 67).
} 
approach fails to notice the dire situation of families of missing persons, particularly if the missing person was the main breadwinner. Furthermore, states tend to apply either measures of reparation or measures of assistance, while the two forms can and should coexist.

States clearly exceed their IHL obligations and provide families of persons missing in the context of armed conflict with more rights than they are obliged to offer under IHL. Moreover, states do not treat the issue of the missing as confined to armed conflict situations. A considerable part of the laws analysed that regulate the legal status of missing persons and provide support for their families comes from South American countries, where the legal framework against enforced disappearances originated. This exemplifies not only the effect that the fight against enforced disappearances has on the situation of missing persons, but also the convergence of IHL and international human rights law. From the perspective of families of missing persons, we should positively assess the choice of states to provide a more protective framework. At the same time, this analysis reveals that the socio-economic needs of families of missing persons remain predominantly unaddressed. 